\title{
Improvement of the methodology of strategic management of the environmental-and- economic development in the region
}

\author{
Andrey Butyrin ${ }^{1}$, Elena Gaganova ${ }^{2, *}$, Olga Pavlyutenkova ${ }^{3}$, and Alexey Nabokikh ${ }^{4}$ \\ ${ }^{1}$ Moscow State University of Civil Engineering, 129337, 26, Yaroslavskoe Shosse, Moscow, Russia \\ ${ }^{2}$ Russia State university of management, Ryazansky Avenue, 99, 109542, Moscow, Russia \\ ${ }^{3}$ Bauman Moscow State Technical University, 2nd Baumanskaya street, d. 5, p. 1, 105005, Moscow, \\ Russia \\ ${ }^{4}$ Vyatka State University, Moskovskaya str., 36, Kirov, 610000, Russia
}

\begin{abstract}
The study justifies the methodological approach to managing the ecological-and-economic development of the region, based on the principle of strategical safe ecological-and-economic development. The analysis of the effectiveness of the strategic decision-making system for the social-and-economic development of the region was carried out. The principal scheme of the decision-making mechanism for the environmental-and-economic development management was developed, including the strategic environmental assessment, which takes into account the ecological and economic state of the region. The proposed methodological approach to the assessment of the ecological-andeconomic situation in the region will allow to reveal some influencing factors, to form the system of assessment indicators, which can be used to control the ecological-and-economic situation and to develop strategical management decisions for the economic development of the region. The scheme of interaction of the strategical managerial decision-making systems as well as the system of regulation of the investment climate in the region can become the basis for the selection of the type of investment policy, corresponding to the ecological-and-economic development of the region. The conceptual framework of decision-making for the ecologicaland-economic development of the region as a management tool will make it possible to choose the environmentally acceptable option for the development and functioning of the balanced environmental-and-economic sector.
\end{abstract}

\section{Introduction}

The global environmental challenges of recent decades have required a shift in the development paradigm as well as some adjustments in the economic growth theory. In this regard, scientific research has shifted towards improving the methodology for the study of environmental matters.

\footnotetext{
* Corresponding author: angela-1309.m@yandex.ru
} 
The reasons for the relevance of the study include:

- the permissibility of the transformation processes, taking place in the environmentaland-economic systems at the global and local levels;

- the exhaustion of the economic growth model, based on the resource approach and the development of the methodology of the theory of welfare economics and social choice, the sustainable development principles;

- conservativeness of the principles of modern policy of the environment protection[1].

The choice of the topic is also defined by the insufficient methodological and methodological support for the study of matters of changing the quality of territorial natural and technical systems, the creation of regulatory systems aimed at the ecological-andeconomic development of the region within the framework of the global human development programme, reflected in the document known as "Millennium Development Goals."

The degree of the problem research development: Theoretical approaches to the ecological-and-economic development are reflected in the model of sustainable development of the world system, which origins are related to the topic of classical economic school (T. Maltus, D. Ricardo, D. St. Miles).

The matters of limited natural resources and the growth of economic entities well-being were considered in the study of problems of economic growth D. St. Mile. The matters of economic growth from the perspective of resource economics were considered in the neoclassical theory by such scientists as D. Meadows, J. Robinson, R. Solow, R. Harrod, A. Pigu. The idea of environmentally sustainable economic growth has been recently developed by X. Daley, R. Goodland, R. Costanz through the restructuring of human development strategies and the provision of concrete solutions. In Russia, the ideas of sustainable development were considered in V. Vernadsky's doctrine on the noosphere and the theory of stability of A. Lyapunov 's states. Strategic aspects of sustainable development of ecological-economic systems were studied in the works of T. Akimov, O. Grunina, V. Gurman, N. Marfenina, E. Ryumina, L. Shakiro, etc. Methodological matters of the development of integrated criteria of sustainable development were analyzed by S. Bobylev, G. Mekush, A. Semin, N. Pakhomova, K. Richter, etc.

Despite the extensive study of the sustainable development matters, the issues related to the content of the concept of safe development of ecological-and-economic systems of the region are not fully reflected, the problems of diagnostics of ecological-and-economic condition of regions as well as the practical use of its results for making management decisions of economic development of the region remain relevant $[2,3]$. The relevance of the problem, theoretical, methodological and practical significance, and the existence of unresolved issues determined the purpose and objectives of this research.

Consideration of the region as an environmental-and-economic system requiring some general forms of managerial decision-making on the economic development, based on the principles of security, is regarded as an environmental-and-economic system, capable of maintaining its basic properties, including its ability to counter threats and destabilizing factors, having common development objectives, expressed peculiarities of economic structure, ecological situation, social priorities arising from the relationship between its subsystems, requiring common forms of managerial decision-making on the environmental economic development.

\section{Methods}

The theoretical and methodological basis of the research are the fundamental provisions of the economic theory, the economics of well-being and public choice, the theory of 
managerial decision-making; the theory of economic efficiency and safety, fundamental concept of sustainable development, etc.

The system analysis, method of comparative, structural-functional, correlationregression analysis, etc., were used for the study of the problems of the social-andeconomic systems stability.

Ecological-and-economic development of the region is the process aimed at maintaining the basic parameters of the ecological-and-economic system within the limits of development, leading to qualitative changes in the reproduction of living conditions and the state of protection of interests of the subjects, due to the action of the economic mechanism based on the economic incentives of environmentally acceptable development [4].

The author forms an approach that differentiates the factors of influence on the ecological-and-economic state of the region by hierarchy, with division into groups of state and environment according to the systematic approach in the study of the matters of the region development and the principles of hierarchy, comparability, dynamism and parity of criteria for selection of new indicators of environmental quality. The environmental factors reflect some qualitative characteristics of the presence of conditions for the formation and functioning of the life environment.

State factors are quantitative characteristics of the potential for self-development and sustainability of reproductive processes. In the classification presented in Table 2 the factors of the first level take into account relationships and interaction of the main subsystems of the region, the second level reveals some conditions, peculiarities of economic potential, ecological situation, the third level characterizes the dynamics of factors of the first and the second levels.

Table 1. Factors of ecological-and-economic state of the region.

\begin{tabular}{|c|c|c|c|}
\hline \multicolumn{4}{|c|}{ he 1st level. Factors of ecological-and-economic state of the region. } \\
\hline & State factors & \multicolumn{2}{|c|}{ Environment Factors } \\
\hline \multicolumn{2}{|c|}{$\begin{array}{l}\text { Natural and production factors contributing to } \\
\text { the ecological-and-economic development }\end{array}$} & \multicolumn{2}{|c|}{$\begin{array}{l}\text { Historical conditions of life, social-and--cultural } \\
\text { environment, innovation-and-investment } \\
\text { environment }\end{array}$} \\
\hline Indicators & $\begin{array}{l}\text { Environmental capacity, } \\
\text { technological intensity, total } \\
\text { man-made load, natural } \\
\text { resource potential, economic } \\
\text { capacity }\end{array}$ & $\begin{array}{r}\text { Cultural-and-ec } \\
\text { infrastructure, inves } \\
\text { legal }\end{array}$ & $\begin{array}{l}\text { ational potential, social } \\
\text { tent-and-financial potential, } \\
\text { ironment, etc. }\end{array}$ \\
\hline \multicolumn{4}{|c|}{ The 2 nd level. Factors derived from the $1^{\text {st }}$ level factors } \\
\hline \multicolumn{2}{|c|}{$\begin{array}{l}\text { Factors determining the state of the } \\
\text { environment, economic capacity }\end{array}$} & \multicolumn{2}{|c|}{$\begin{array}{l}\text { Factors determining the quality and efficiency of } \\
\text { the infrastructure }\end{array}$} \\
\hline $\begin{array}{l}\text { Level of } \\
\text { technogenic } \\
\text { influences }\end{array}$ & $\begin{array}{l}\text { Level of economic } \\
\text { activities }\end{array}$ & Legal framework & $\begin{array}{l}\text { Efficiency of administrative } \\
\text { structures }\end{array}$ \\
\hline $\begin{array}{l}\text { Level } \\
\text { engineering } \\
\text { and } \\
\text { production } \\
\text { structures } \\
\end{array}$ & $\begin{array}{l}\text { Level of transport and } \\
\text { communication } \\
\text { infrastructure }\end{array}$ & $\begin{array}{l}\text { Existence of the } \\
\text { mechanism for the } \\
\text { regulation of the } \\
\text { investment climate }\end{array}$ & $\begin{array}{l}\text { Development of the social } \\
\text { infrastructure, degree of } \\
\text { influence of traditions, etc. } \\
\text { manner }\end{array}$ \\
\hline
\end{tabular}




\begin{tabular}{|c|c|c|}
\hline Indicators & $\begin{array}{l}\text { The share of industrial products of the enterprises, } \\
\text { using the natural resources in the total volume of GRP } \\
\text { of the territory, structure-forming indicators of GRP; } \\
\text { share of environmental core production assets in the } \\
\text { total core production assets; level of man-made } \\
\text { influence on the main elements of the environment; } \\
\text { the incidence rate of the population living in } \\
\text { ecologically the disadvantaged territories, etc. }\end{array}$ & $\begin{array}{l}\text { Level of budgetary funding } \\
\text { for the environmental } \\
\text { activities; degree of the } \\
\text { development of health, } \\
\text { education, housing-and- } \\
\text { communal infrastructure; } \\
\text { life expectancy, level of } \\
\text { housing provision }\end{array}$ \\
\hline \multicolumn{3}{|c|}{ The 3rd level. The factors of the $2^{\text {nd }}$ level factors dynamics } \\
\hline \multicolumn{3}{|c|}{ Factors determining the dynamics of the second level factors (conditions and environments) } \\
\hline Indicators & $\begin{array}{l}\text { Growth rate of the mineral resources consumption for } \\
\text { the production purposes; the ratio of extractive } \\
\text { industries to industrial production; rate of the increase } \\
\text { in emissions, discharges, waste disposal; rate of the } \\
\text { increase in morbidity due to the environmental factor, } \\
\text { progress in the commodity and consumer price } \\
\text { indices, etc. }\end{array}$ & $\begin{array}{l}\text { Level of social-and- } \\
\text { demographic investments; } \\
\text { fertility to mortality ratio } \\
\text { per } 1,000 \text { persons, ratio of } \\
\text { population spending growth } \\
\text { for treatment in areas with } \\
\text { the ecologically } \\
\text { disadvantaged situation } \\
\text { with the income growth, } \\
\text { etc. }\end{array}$ \\
\hline
\end{tabular}

\section{Results and discussion}

Approach to the research of a region as to a uniform ecological-and-economic system allows to consider the property of strategically focused safe development in the establishment of criteria and parameters of the assessment of the ecological-and-economic level. The application of the approach in the analysis of the threats impact on the principal properties of the ecological-and-economic systems (Table 2) [1,5] demonstrates that the condition of the system security is determined by the criteria estimating "ability to resist to destabilizing factors" and by the "self-development" properties as they face the greatest consequences.

Table 2. Impact of threats on the principal properties of the ecological-and-economic system.

\begin{tabular}{|c|c|c|c|}
\hline Properties & Criteria & $\begin{array}{l}\text { Types of threats to the } \\
\text { pronciple properties }\end{array}$ & Consequences \\
\hline $\begin{array}{l}\text { Ability to } \\
\text { self- } \\
\text { development }\end{array}$ & $\begin{array}{l}\text { Sufficiency of } \\
\text { resources for } \\
\text { simple and } \\
\text { extended } \\
\text { reproduction }\end{array}$ & $\begin{array}{l}\text { Exhaustion of natural } \\
\text { resources. Non-rational use } \\
\text { of not renewable and } \\
\text { renewable natural resources. } \\
\text { High wear of fixed assets, } \\
\text { including nature protection } \\
\text { inventory and constructions. } \\
\text { Imperfection of the } \\
\text { legislative base and economic } \\
\text { mechanism of nature } \\
\text { protection activity and } \\
\text { environmental management. } \\
\text { Emergency situations of } \\
\text { natural origin. Body height of } \\
\text { volume of the use of natural } \\
\text { resources. }\end{array}$ & $\begin{array}{l}\text { The decrease in the } \\
\text { ecological capacity of the } \\
\text { territory. The termination of } \\
\text { activity of the companies, } \\
\text { using the natural resources, } \\
\text { and the enterprises of the } \\
\text { local industry. Loss of jobs } \\
\text { and the decrease in rates of } \\
\text { economic body height. Crisis } \\
\text { situations in economy: delay } \\
\text { of rates of development } \\
\text { because of impossibility of } \\
\text { placement of the new } \\
\text { enterprises and development } \\
\text { of infrastructure, etc. }\end{array}$ \\
\hline $\begin{array}{l}\text { Ability to } \\
\text { resist to }\end{array}$ & $\begin{array}{l}\text { Existence of } \\
\text { adaptive }\end{array}$ & $\begin{array}{l}\text { The decrease in the reserve of } \\
\text { ecological capacity, techncal }\end{array}$ & $\begin{array}{l}\text { Economic damage from the } \\
\text { environment pollution (E), to }\end{array}$ \\
\hline
\end{tabular}




\begin{tabular}{|l|l|l|l|}
\hline $\begin{array}{l}\text { destabilizing } \\
\text { factors }\end{array}$ & $\begin{array}{l}\text { mechanisms to } \\
\text { the external } \\
\text { influences }\end{array}$ & $\begin{array}{l}\text { capacity and assimilatory } \\
\text { capacity of the territory. } \\
\text { Errors in the expert research } \\
\text { at expansion of the a } \\
\text { technosphere and } \\
\text { unsatisfactory predictability } \\
\text { of natural disasters of natural } \\
\text { character. The increase in } \\
\text { anthropogenic loading, etc. }\end{array}$ & $\begin{array}{l}\text { the population health. } \\
\text { Emergence of zones of } \\
\text { disaster because of loss of E } \\
\text { of property of the } \\
\text { autoreduction. "Pressure" of } \\
\text { society upon the nature } \\
\text { surpassing opportunities body } \\
\text { height of ecological costs and } \\
\text { inefficiency of economy is } \\
\text { restored. The decrease in } \\
\text { costs for restitution and } \\
\text { compensation. Manifestations } \\
\text { of a technogenesis at the } \\
\text { global level. }\end{array}$ \\
\hline $\begin{array}{l}\text { Ability to } \\
\text { provide } \\
\text { interaction }\end{array}$ & $\begin{array}{l}\text { Availability of } \\
\text { balanced } \\
\text { development } \\
\text { of all the } \\
\text { subsystems }\end{array}$ & $\begin{array}{l}\text { The use of technologies, } \\
\text { ecologically incompatible } \\
\text { with habitat, and technical } \\
\text { means. Violation of natural } \\
\text { equilibrium of natural } \\
\text { systems. Involvement of the } \\
\text { public ecological benefits in } \\
\text { the market turnover }\end{array}$ & $\begin{array}{l}\text { Structural change of final } \\
\text { consumption. Exhaustion of } \\
\text { principle elements of the } \\
\text { environment on the main } \\
\text { components. Increase in the } \\
\text { industrial expansion, etc. }\end{array}$ \\
\hline
\end{tabular}

The results of the analysis of the impact of threats and the system of criteria in serial decomposition on the basic properties of the ecological-and-economic system presented in Table 2 demonstrate that the criteria defining a condition of the safety of the ecologicaland-economic system are: "existence of adaptive mechanisms to external influences" and "sufficiency of resources for prime and a breeding". On the basis of the parameters regulating use of natural and resource and economic capacity of the region, characterizing stability of its state the environment tekhnoyemkost, technogenic load of a surrounding medium and economic capacity are defined (Table 1) [1,6,7]. On their basis the model of the integrated indicator defining change of ecological-and-economic loading of the region is under construction.

The resource and indicative-and-index approaches, accepted for the evaluation of the environment (E) and environmental safety of the territory, reveal as ecologically focused, but the poorly bound to the growth of social-and-economic potential and features of the economic development of the region.

The indicative approach, based on tracing and indexes, recommended by the World Bank and the Commission on sustainable development at the UN and also some other the International organizations, characterizes a condition of environmental safety by the indicators structured on environment elements. However the indicators of the condition of the environment on the degree of completeness and a significance have different space-time distribution and serve in the basic for comparison at the macrolevel. So, the ecological measurement index (EMI) having a high level of aggregation (calculated on the basis of 76 sets of ecological data), serves for intercountry comparison; the index of environmental efficiency (EE) "degradation of ecosystems" reflects assessment of current state of the environment on the components and "natural resources", however it cannot be used for the assessment of the level of safety of the ecological-and-economic system [8].

The resource approach applies the indicators of the state characterizing generally chemical composition of a controlled subject, estimating the degree of compliance of current state of the environment to the adopted standards. And though it creates conditions of safety of ecological systems of the region, isn't reached complex assessment of level of environmental safety as the major ecological parameters, such as ecological capacity, technology intensity of the environment, characterizing the equilibrium of natural systems 
are normatively not fixed in it. Besides, the applied indicators are poorly combined with the requirements imposed by information systems and the systems of decision making [9].

The industrialized regions, being the main users of natural resources, most often demonstrate themselves as resource-type territories, which main activity is mining, supply, complete or partial processing of minerals. The creation of the investment climate and the assessment of investment attractiveness in such regions should be based not only on the traditional commercial approach, but also on the environmental factor. The most important condition for the favorable investment climate maintaining of the region is the compliance of the investment supply of resource-consuming production complexes with the quality of the natural and human environment. On this basis, the development of the investment climate of resource-type regions should focus on the priorities of environmental-andeconomic development. Therefore, the scheme of interaction of the mechanism of making strategic managerial decisions and regulating the investment climate of the region should include the stage of formation of the appropriate type of investment policy, which corresponds to the ecological-and-economic state of the region (Fig.1).

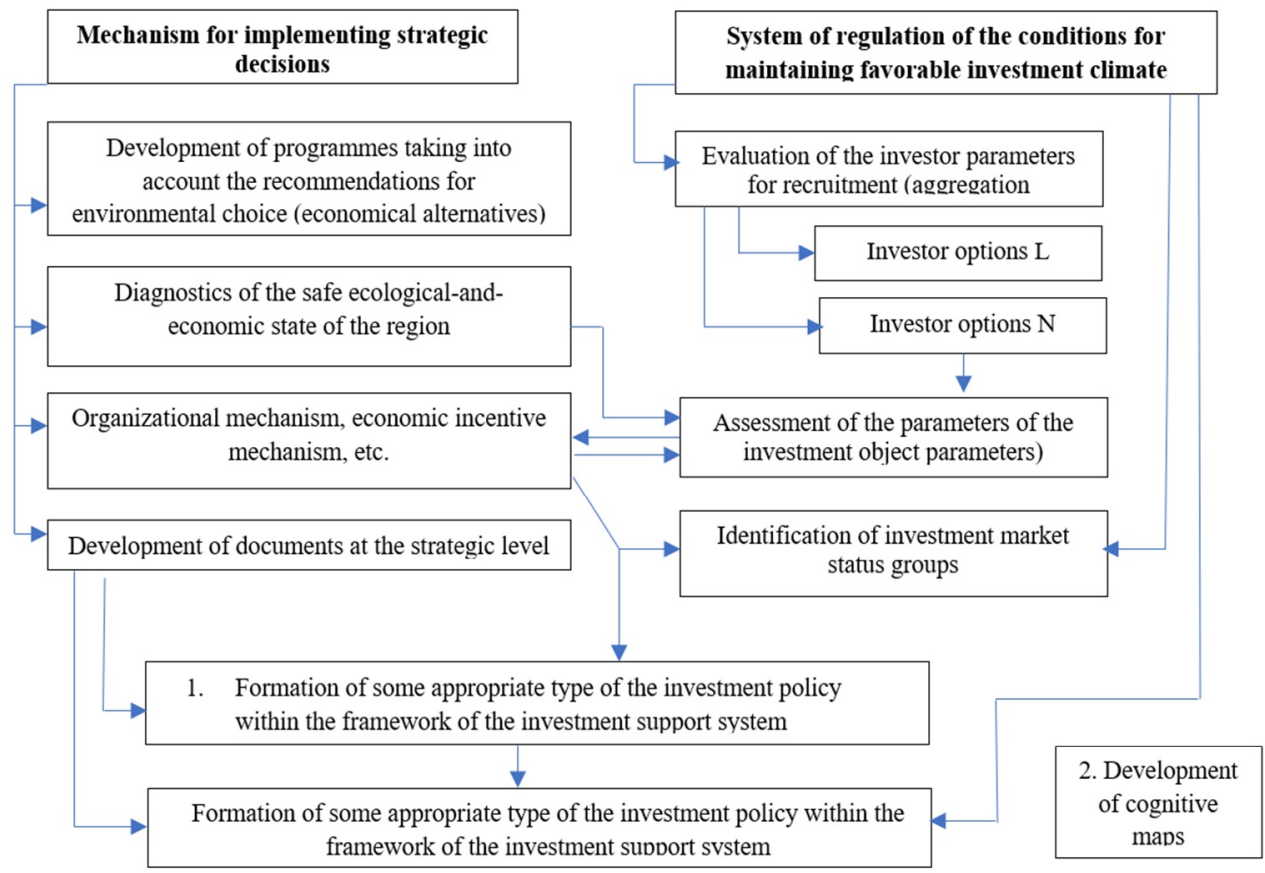

Fig. 1. Scheme of interaction of the systems for making strategic managerial decisions and regulation of the investment climate in the region.

It is necessary to introduce the block of the environmental-and-economic diagnostics into the structure of the strategic decision-making system to make strategic decisions on the management of the ecological and economic development of the region $[1,10]$.

The regulatory framework for strategic planning and approved methodologies for the development of strategic-level documents in the development of the state forecasts and the social-and-economic development programmes suffers the lack of the rules governing the process of carrying out the strategic environmental assessment and the organizational mechanism for consolidating the results of environmental monitoring and assessment. At the same time, the current system of formation and selection of the strategy of socio-andeconomic development of the region takes into account only the types of economic activities, which development is unacceptable in the territory, and international obligations 
in the context of transboundary pollution, and hardly takes into account the level of environmental restrictions, changes in the quality of the natural environment, etc.

Environmental-and-economic development, as the process aimed at maintaining the key parameters of the system within certain limits, provides the controlled impact not only in the implementation of the decisions taken, but also in the stages of the strategy formation.

The starting point of the direction of development is the strategic analysis, which includes the assessment of the ecological-and-economic state (EES).

The final documents developed at the stage of strategic analysis are: list of causes of problem environmental situations, assessment of the consequences significance, the list of priority environmental-economic restrictions, consolidated assessment of EES. In this regard, the mechanism for making strategic decisions on the environmental-and-economic development management in its structure should contain the following stages: analysis and formation of the environmental alternative, selection, formalization and implementation of the chosen development strategy[1, 3-5]. The proposed mechanism for the implementation of strategic decisions includes the set of methods of economic stimulation, legal regulation, organizational measures, assessments of the investment opportunities, sources of financing and the system of choosing the type of investment policy (Figure 2).

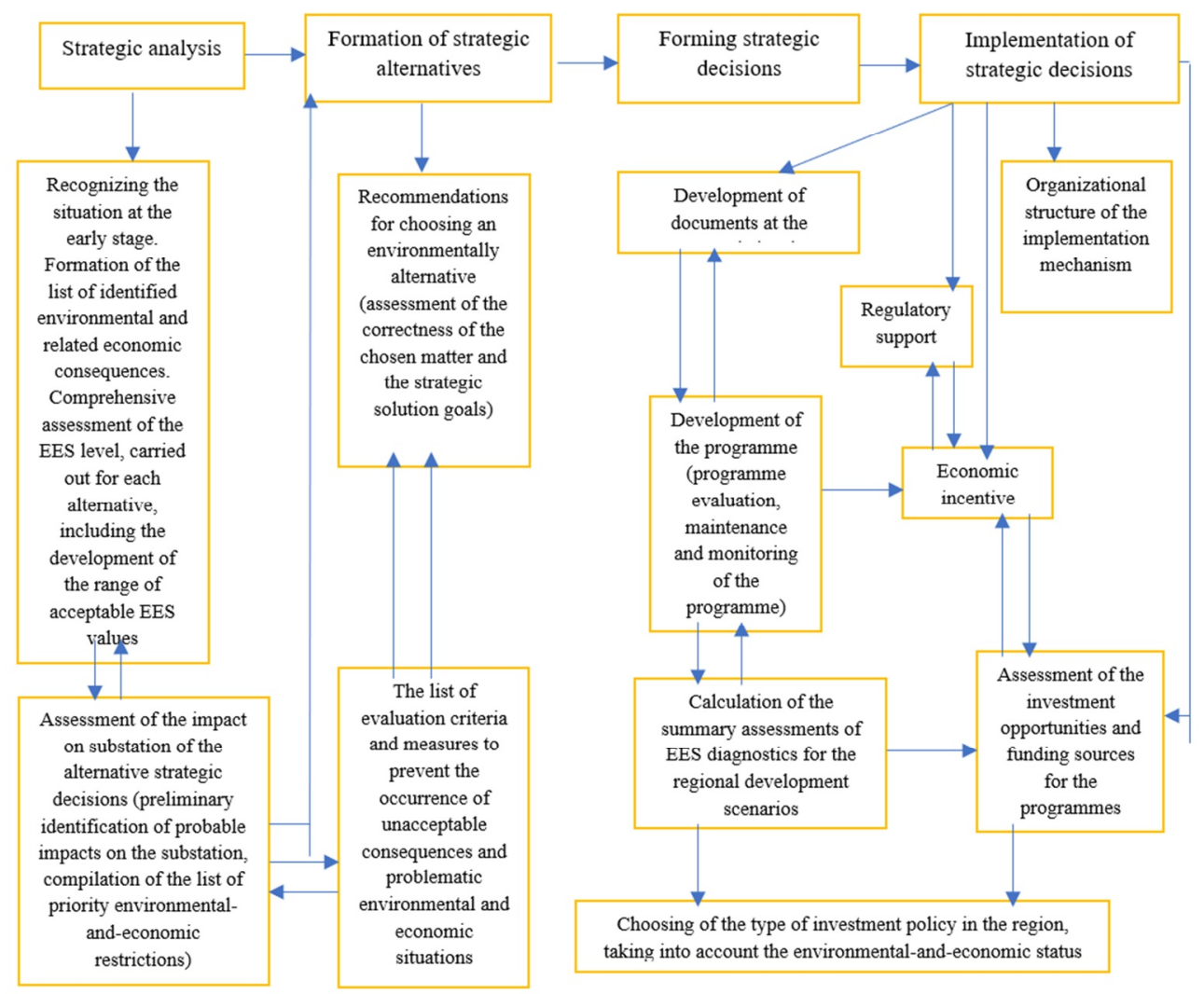

Fig. 2. Conceptual scheme for making strategic decisions on managing the environmental-andeconomic development of the region.

The results of the analysis are used in the strategic alternatives phase to develop the criteria and the list of measures to prevent unacceptable effects that serve to select an environmental alternative. The proposed safety criterion in the conceptual framework is included in the list of criteria for assessing measures to prevent problematic environmental- 
and-economic situations and is taken into account when choosing an environmental alternative.

The strategy selection and formalization phase acts as the basis for long-term and programmatic-targeted planning. The results of the environmental-and-economic state diagnostics obtained for each identified alternative are specified at this stage in the assessments on the selected direction of development of the region and on the importance of problem environmental situations affecting the ecological-and-economic state.

The stage of implementation of the chosen strategy includes the organizational block, blocks of regulatory-and-legal support, economic stimulation, assessment of investment opportunities of the region.

The most important condition for the regions characterized by mass use of reproducible and non-reproducible natural resources (resource-type regions) is to ensure reproduction of the natural resource subsystem. So, it is envisaged that the economic incentive mechanism for the ecological-and-economic development of the region will include the methods of demanding and stimulating nature. The traditional stimulating methods include:

- Differentiation of land prices and housing fees according to environmental factors;

- Special tax regimes for regions of special ecological-and-economic status;

- Concessional lending of projects using low-carbon technologies, tax incentives to economic entities participating in the system of state partnership in the directions (energy saving, forest management, waste processing);

- Preferential depreciation system for cleaning equipment, etc.

Demanding methods should be tightened in the terms of payments for pollution:

- Taking into account the population health damage from specific types of pollutants when justifying the pollution charges;

- Liability insurance regimes for the environmental damage.

The measures noted in the economic practice in determining the efficiency of the region 's economy reduce the underestimation of economic indicators by environmental parameters.

The proposed conceptual scheme for the management of the ecological-and-economic development of the region, based on an environmentally sound version of economic growth, focuses on controlled resource consumption, creates prerequisites for the transition to a technological system that implements the condition of environmentally balanced economic development.

\section{Conclusions}

1. The proposed methodological approach to the assessment of the ecological-andeconomic state of the region will allow to reveal the influencing factors, to form the system of assessment indicators, which can be used in order to control the ecological-andeconomic situation and to develop the strategic managerial decisions for the economic development of the region.

2. The scheme of interaction of the system of strategic managerial decision-making and the system of regulation of the investment climate of the region can become the basis for the selection of the type of investment policy corresponding to the ecological-and-economic development of the region.

3. The conceptual framework for decision-making on the management of the ecologicaland-economic development of the region as a management tool will make it possible to choose an environmentally acceptable option for the development and functioning of a balanced environmental-and-economic sector. 


\section{References}

1. I.S. Velik, Impact of Environmental-Economic Security on Justification Strategic investment decisions: monograph (UGTU-UPI, Yekaterinburg, 2008)

2. A.G. Granberg, Strategy and Problems of Sustainable Development of Russia in the XXI Century (Publishing House: Economics, 2019)

3. V.A. Zhukova, International scientific journal Synergy of Sciences 138 (2018)

4. E. Vasilyeva, A. Mottaeva, E3S Web of Conferences 91, 08051 (2019) doi.org/10.1051/e3sconf /20199108051

5. A. Mottaeva, A. Borisova, E3S Web of Conferences 138, 02015 (2019) https://doi.org/10.1051/e3sconf/201913802015

6. E.M. Akhmetshin, Entrepreneurship and Sustainability Issues 7(2), 1089-1097 (2019) doi:10.9770/jesi.2019.7.2(21)

7. K.S. Mullakhmetov, E.M. Akhmetshin, 31st International Business Information Management Association Conference, IBIMA 2018: Innovation Management and Education Excellence through Vision 2020, 3573-3581 (2018)

8. N.V. Tsopa, Economics and ecology of territorial entities 2, 15-21 (2017)

9. E.V. Scherbakov, Journal of LNU named after Taras Shevchenko 3(19), 68-74 (2018)

10. E. Ganebnykh, T. Burtseva, A. Petuhova, A. Mottaeva, E3S Web of Conferences 91, 08035 (2019) doi.org/10.1051/e3sconf /20199108035 